\title{
The Genres and the Uses of Oral Literatures in the Utterances of Sayyid Haji Ali Wale and Sayyid Roba Garbi in Bale Zone, Oromia
}

\author{
Umer Aliy \\ Department of English Language and Literature, College of Social Sciences and Humanities, Madda Walabu \\ University, Robe Bale, Ethiopia \\ Muktar Ahmed \\ Department of English Language and Literature, College of Social Sciences and Humanities, Madda Walabu \\ University, Robe Bale, Ethiopia
}

\begin{abstract}
The major objective of the study was to find out genres anduses of oral literatures in the utterancesof Sayyid Haaji Ali Wale and Sayyid Roba Garbi in Bale Zone, Oromia.The study was conducted in Goro woreda of Bale zone since the two famous persons had been living in different areas of the woreda for a long period of time. To achieve the research objectives, qualitative research approach was employed, for it can guide the researchers to collect qualitative data. From the woreda, 8 kebeles were selected purposively.In this manner, five elders were selected from each kebele by using snowball sampling technique; therefore, 40 elders were selected and five elders were taken from Goro town. Totally, 45 elders were involved in the study from whom the data was collected through semi-structured interview and focused group discussion. Besides, oral literatures of the two famous persons were collected from related written materials usingdocument analysis. After that, the collected data were carefully transcribed, and analyzed critically according to their aspects. Thus, the results of the study show that the oral literatures that the two famous persons used have different genres and short structures with broad matters. Genres such as short stories, short sayings, proverbs, blesses, curses and songs are the majors. The study reveals that they used these oral literatures to create the awareness of youngsters to wardseducation, hardworking, truthfulness, patience and future wish.Thus, different stake holders can use this indigenous knowledge in various aspects.
\end{abstract}

Keywords: Genres, use, Oral literature, Utterances, Oromo, Bale.

DOI: $10.7176 / \mathrm{JLLL} / 62-03$

Publication date: November $30^{\text {th }} 2019$

\section{Introduction}

\subsection{Background of the Study}

Oral literature is a tool used to transmit culture, values, norms, language, history of a nation and so on from generation to generation particularly in Africa. Africans have conserved their cultures and history using oral literatures. Their ways of lives, economy, believes... can be inferred from oral literatures such as heroic songs, music, drama, proverbs, narratives, tales or short stories etc."Before things fall apart, from the Stone Age to the Bronze Age and to the Iron Age, the fortune of African folk narratives was unmistakably impressive and encouraging. And also literature, as a reflection of life and human activities, expresses human experiences and culture" (Sikiru 2015: 180).

As other Africans, Oromo people have preserved and transmitted their traditions using oral literature for Oromo written literature has started recently. Moreover, Oromo language, culture and history have not been developed because of political situation in Ethiopia for a century. As Moti stated in his book titled 'Oromian Befereka??' Oromo language has been blocked from using it in mass media, to be written language and language of education because the dictators follow one language policy (Amharic). Therefore, to survive their culture, norms and values, the major tool Oromo people have used is oral literature.

Africans (Oromo people) use oral literature for different functions. Researchers have explained functions of oral literature used in Africa. Functions of African oral literatures, as cited in Jeylan (2005:15), are:

The African oral traditions facilitate the transmission of knowledge and conventions from generation to generation. The economic structure and relationships, political traditions and practices, social rules and values of the African societies are still transmitted orally.

Moreover, Muktar and Oumer (2010) also stated the functions of Oromo oral literature in the following poem which Bale Oromo women have used to express the hazard they faced because of feudal system in Ethiopia.

Qunnaa saddeet na daaksiftanii you forced me grinding eight 'qunna'

Qarshii hin dandeenye jaarsa baachistanii you collected difficult money from my husband

Rabbii adda moohee, ani sitti boohe.God, who is the only winner, I appeal to you. 
Osoo sii daakuu jilba fixee; in pounding for you (dictator), I have finished my kneel;

Osoo sii daakuu majjee fixee; in grinding for you, I have finished 'majjee';

Osoo sii daakuu maccee fixee; In grinding for you, I have finished 'maccee '(energy).

Sii daake qunnaa; ofii daaqe humnaan. I have grinded 'qunna' for you; I myself, has tired out.

As can be read the above quote, communities use oral literature in various ways to express their deep feelings, joy, frustration and life experiences and values. Regarding this Berhanu (2013:13) states, "Oral literature still plays significant role in the culture of various people in the world." He also stated that in developing countries like Ethiopia oral literature still plays significant role in expressing the people's life experiences. Furthermore, Finnegan (1970:329) explained that stories for example are told to educate and socialize children or by drawing a moral to warn people not to break the rule of society. Oral literature in the form of storytelling has traditionally been the most popular indigenous way of transmitting societal values (Encarta: 2009).

Thus, the present study was conducted to identify genres of oral literatures used by Sayyid Roba Garbi and Sayyid Haji Ali Wale in their speeches and analyze for what purpose they used oral literature in different aspects.

\subsection{Statement of the Problem}

Traditionally, African elder's clan, tribe and village leaders and elders have used oral literatures in their speeches. In Africa, elders who use different oral literatures in their speeches considered as wise, intelligent, experienced and good negotiators. It is said beside Oromo, "A speech that lacks proverb is similar to meal without salt (Dubbiin mammaaksa hin qabnee fi nyaanni sogiddaa hin qabne takka).

Similarly, according to Oromo people (Bale Oromo), there are different group of people: Qallu (religious elders), jaarsa biyyaa or jaarsa gandaa (village elders), hayyuu (wise person), luba, heroes, heroines, etc. Sayyid Roba Garbi and Sayyid Haji Ali Wale Wako were one of the famous persons whose speeches used among the people and passed from generation to generation. Sayyid is Arabic word which means "a title that has similar meaning of English title: master or mister, or sir; in other word, the Arabs used to call tribal leaders and elders "Sayyid" (e.g. Sayyid Bani Foolaan - the leader of such-and-such tribe, etc) (https://en.wikipedia.org/wiki/Sayyid 3/15/19)" . In their life hood, they used to lead and educate people in different aspects.

However, the oral literatures they used in different aspects are fragmented beside few individuals elders. In related to this, the previous studies that have been conducted on this issue are not observed yet. Only the study that has been conducted by Muktar and Oumer (2010) with the title "Thematic Functions of Oral Literatures in the Speeches of Legendary Oromo Heroes in Bale Zone, Oromia" is viewed. As it is indicated, the study emphasized the oral literatures used by heroes; such as, General Hussein Bune, Haji Adam Saddo, Colonel Aliy Cirri,General Wako Gutu, and Colonel Adam Jilo.By the study, a lot of oral literatures that were used by these heroes were collected and analyzed with respect to the functions they were used for. Even if Sayyid Roba Garbi and Sayyid Haji Ali Wale are famous in extended areas with their plenty of oral literatures, life experiences and sayings, a due credit has not been given for them, particularly, the oral literatures they used in various aspects. According to the existing realities, elders of the area talk the life history and sayings of the two famous persons while they make talk with youngsters. Moreover, elders use oral literatures used by these two famous persons to educate, advise, instruct, guide and prohibit youngsters to/from different phenomena. However, they are dispersed and a few people are knowledgeable about it that is why the researchers were interested to conduct this study based on the following research objectives.

\subsection{Objectives of the Study}

The major objective of the study was to find out and analyze genres and uses of Oral literatures in the utterances of Sayyid Roba Garbi and Sayyid Haji Ali Wale ofBale zone, Oromia region. Along with the general objective, the study was carried out on the basis of the following two specific objectives. These are:

1. To find out genres of oral literatures in the utterances ofSayyida Roba Garbi and Sayyid Haji Ali Wale Wako.

2. To analyze for what purposes did they use oral literatures in their utterances.

\section{Review of Related Literature}

\subsection{History of Sayyid Haji Ali wale Wako}

As the elders told, Sayyid Haji Ali Wale Wako was born in Goro Woreda in the place called Rowda. His clan which is Ilani belongs to five siko's clans: Wucale, Bullala, Waji and Ilani. He lived in the world for one hundred ten years. It was 120 years ago since he passed away. Because the data was collected in 2010 (E.C), his death year could be in $1880\left(2010 \_120=1880\right.$ years $)$. In addition, thus his birth year can be estimated (his death year - years he lived in this world $=$ his birth year: $1880-110=1770)$. As elders' response, he had a lot of wives even if only four of them were famous. These were Rahima ,Fatuma, Bilkisa and Hawe. Sayyid Haji 
Wale Wako had many daughters and sons. Some of them were kedir, Muhammed, Sayyid Abdullah, Sh/Hasan, Sh/Usman, Jamile, Kabir Hussein, Hasna, Kadija, shashu, Sh/Rashid, Sh/ Adem, etc. All of them were not alive. Sayyid Haji Ale Wale Wako devoted majority of his life in teaching Islamic religion and he also paid a great contribution in different aspects.

\subsection{History of Sayyid Roba Garbi}

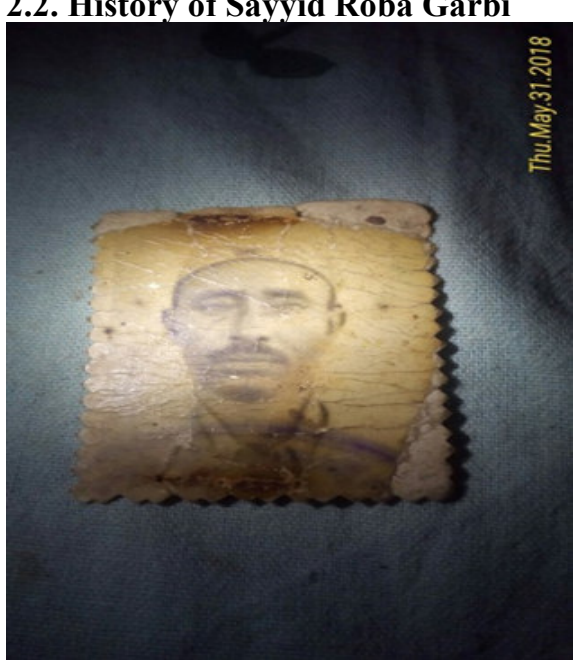

Photo of Sayyid Roba Garbi, taken from his ID. Card, May 15, 2018 G.C.

Sayyid Roba Garbi was very famous person in Ethiopia as well as Kenya country. He passed away in Kenya and his body was taken back to Ethiopia and was buried in Dabaye village Goro Woreda Bale zone. He had a lot of wives and daughters and sons. Majority of his family lives in three villages in Goro woreda: Dabaye, Malka Butta and Kekku. In his life, going in different parts of oromia, he taught Oromo people as they proud of themselves and he inspired them as Oromia will be free from oppressors (Aman Nesha, 2010). Aman Nesha (2010) also said that, "Sayyid Roba can be called as political analyst of the world." He gave commendations or lessons dramatically. He used to forecast future events by analyzing current situations. For example, during Haile Selassie regime, he gathered people under a tree in Dello, and ordered three people. He ordered one man to climb the tree up to the peak, the second man to the middle of the tree and the third man to stand by tree on the ground. Sayyid Roba ordered the man at the peak of the tree, "say! Haile Selassie was dead." At that time the emperor was alive and he was not sick. The man tried to refuse to say what Sayyid Roba ordered him to say because there was policy at the place. However, Sayyid Roba said to the man, "Either you say or your life period must be shortened." Other people were observing the situation. Finally, the man said three times, "Haile Selassie was dead, Haile Selassie was dead, and Haile Selassie was dead." Sayyid Roba ordered the man at the middle of the tree to say three times, "feudalists were disappeared." The man took the order and said, "Feudalists were disappeared, feudalists were disappeared, feudalists were disappeared." He, Sayyid Roba, told the man on the ground as he says, "Sayyid Roba was dead". The man said, "Sayyid Roba was dead, Sayyid Roba was dead, Sayyid Roba was dead." He forecasted and taught people the order these events happened: death of the emperor, disappearance of feudalists and death of himself.

\section{Methodology of the Study}

\subsection{Description of the Study Area}

This study was conducted in Goro woreda of Bale zone. The woreda is exclusively linked with the history of famous persons under study as their living areas. These famous persons are:- Sayyid Haji Ali Wale Wako and Sayyid Roba Garbi. Goro woreda (the capital town) is $60 \mathrm{~km}$ far away from Robe, the capital town of the Bale zone. The majority of the woreda's people life is based on agriculture.

\subsection{Design of the Study}

To achieve the objectives of the study, qualitative research approach was employed. In addition, the researchers used interpretive approach for analysis purpose. The qualitative approach emphasizes on processes and meanings that are not measured in terms of quantity, amount, intensity or frequency. Thus, the researchers used this approach because it provides a deeper understanding of the phenomenon within context (Guba and Lincoln, 1994). Moreover, it enabled the researchers to collect relevant data from the target subjects using appropriate data collection tools like interview, focused group discussion and document analysis. 


\subsection{Subjects of the Study}

The target subjects of the study are elders, for they are resourceful in oral literature in general and famous people's literatures in particular. Specially, elders, who were living in the woreda of these famous persons, were expected more in raising different genres of oral literature used in the utterances of those famous persons legendary life. Hence, the researchers mainly focused on elders who had more information about the legendary life of both famous persons.

\subsection{Sample Size and Sampling Technique}

Goro woreda (district) has fifteen kebeles and one capital town.To get more information, from the 15 kebeles, eight kebeles were selected purposively .i.e. Malka Butta, Kekku, Dabeye (Waltae Sayyida), Balle Alem Kerem (Rawda), Garre, Maliyou Burka,Balle Sole, and Goro Rayya. The four kebeles mentioned first are the places where these famous persons lived for a long of time and their families and relatives have been living; besides among these kebeles, Dabeye(Waltae Sayyida) and Balle Alem Kerem (Rawda), are where the bodies of these famous persons, Sayyid Roba Garbi and Sayyid Haji Ali Wale respectively, buried. The other four kebeles are nearby or neighbors to the other four kebeles listed respectively and the researchers believed that information related to this study can be gained from the all mentioned kebeles, so they were selected purposively. In addition, the capital town of the woreda (Goro town) was also selected purposively since the elders who know these famous persons live in the town.

From each selected kebele or village, five elders were selected by using snowball sampling technique; therefore, 40 elders were selected. Similarly, five elders were taken from Goro town. Thus, 45 elders were the participants of the study, for they are more knowledgeable in using oral literatures and closed to these famous persons in terms of age when it compared to other groups such as youth.

\subsection{Data Collection Tools}

To collect relevant data, the researchers used three data collection tools. These are like semi-structured interview, focus group discussion and document analysis. The items of both interview and focus group discussion were translated into Afan Oromo and the face to face interview as well as group discussion was held in Afan oromo with the target participants. In this manner, the interview was conducted with 32 elders in their respective kebeles whereas FGD was also carried out with thirteen (13) elders of whom five (5) elders were selected from Goro town and eight (8) elders were taken from the selected kebeles. Similarly, document analysis was used as additional tool to collect relevant data from previously written materials that are related to the topic under study.

\subsection{Procedures of Data Collection}

To collect data successfully, the researchers prepared data collection tools' items and check them clearly. Second, they went to the research sites having legally written letter by Madda Walabu University Research, Community Engagement and Technology Transfer (RCETT) vice president office. Third, they contacted the target participants and arranged the schedule with them. Then, the interview was held with the selected elders. Similarly, focused group discussion (FGD) was carried out with the selected 13 elders in Goro town arranging them in one group. In this regard, both interview and FGD discussion was held in Afaan Oromo along with taking short notes and recording their sounds. Besides, document analysis was made by the researchers to get additional oral literatures used by Sayyid Roba Garbi and Sayyid Haj Ali Wale from related written materials. Finally,the collected data was analyzed.

\subsection{Methods of Data Analysis}

Following the successful collection of data, the researchers transcribed carefully both the recorded sound and shortly taken data for analysis purposes. Then, they arranged the transcribed data under headings and subheadings according to their similarities. Finally, the analysis of each data was carried out successfully using interpretive approach.

\section{Data Analysis and Presentation}

\subsection{Sayyid Haji Ali Wale and Sayyid Roba Garbi's Genres of Oral literatures and their uses in different} aspects

According to the gathered and analyzed data shows, the two famous persons used oral literature genres in their speeches for different purposes. Particularly, the genres of oral literature they used are short saying, short story, proverbs, blesses, curses, and songs.

The collected data reveal that both famous persons used genres of the above oral literatures in different aspects. These are discussed deliberately as follows.

\subsubsection{Oral Literatures they used for the Importance of Education}

Education is a source of knowledge. Hence, they encourage youths and other people towards the importance of 
education through using oral literatures.

\subsubsection{Short Sayings}

i. $\quad$ Sayyid Haji Ali Wale Wako ordered people that "Educate both your sons and daughter; knowledgeable person is always needed, the educated person's sweet never be finished, never be inexpensive. (Ilmaan keessan barsiifadhaa; nama waa beeku yeroo hundaa itti hajaman; mi'aan isaa hin dhumu, hin rakasus)", (from interview and FGDs).

From speeches of Sayyid Haji Ali Wale Wako, it can be concluded that an educated person should be a leader, education is essential for one country and knowledge is the most expensive. Moreover, the quote informs that education is important both for male and female.

ii. $\quad$ Sayyid Roba said, "Silly person says, 'Oromoo never be free from oppression'. But, I guarantee or swear to God; Oromo will liberate themselves (Gowwaan nama Oromoon akka gabroomtee hin bilisoomtu jedha. Rabbitti kakadhee Oromoon bilisoomtu malee hin haftu.)".

In the above short saying, Sayyid Roba Garbi made speech related to the insight level of a silly person. The message of this lesson is that the advice (idea) of the foolish is not acceptable since the ability they can forecast the future is low.

iii. They said, "There is knowledge that engulfs other knowledge; a person who has achieved it has stability and patience (Beekumsa beekumsa liqimsitutu jira; namni isii argate hinjarjaru hin aaru)". In addition, they said that an individual should have long idea, not shorten his/her idea or vision (Namni yaada dheerachuu qaba malee yaada gabaabbachuu hin qabu) (interview).

From these speeches, it can be inferred that having high level of knowledge is significantly more important and knowledge level of a person should be ranked and let every person has future plan and wish to have not small thing.

As the data collected from interview and FGDs mentioned characteristics of different persons that the two famous persons have used in their speeches:

iv. There are two types of silly persons ( gowwaa gosa lamatu jira).

1. Fat foolish persons (gowwaa furdaa); their characteristics are:

$\checkmark \quad$ qabeenya isaa bakkuma argetti facaasa (he/she never manages and saves his/her property and expends his/her wealth everywhere)

$\checkmark$ dubbatu arraba (his/her talk is insulting)

$\checkmark$ komii baay'isa (blames others or expects everything from other persons)

$\checkmark$ nadaamaa baay'isa (repeat regret more about past or his or her attention is on past events)

$\checkmark \quad$ ija babaasa ( his/her fright is understandable from his/her eyes)

2. Thin foolish persons (gowwaa qal'aa): they have four characteristics:

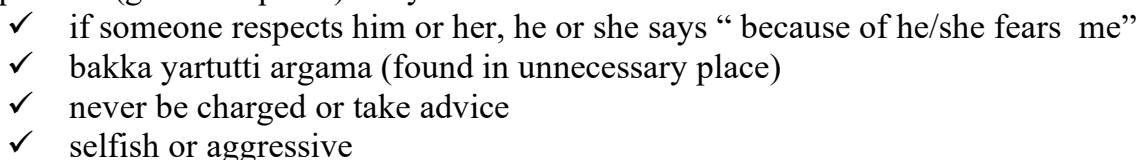

The famous persons also said that unknowledgeable person is corpus, animal; illiteracy lowers the status of a person. They also said, "the wealth of an illiterate person belongs to a literate person or it is the wealth of an educated person (Namni waa hin beeyne beeylada,reeffa,.wallaalli sadarkaa namaa ajjeesa; qabeenyi nama waa hin beeknee kan nama waa beekuti)."

From this it can be concluded that it is likely difficult for an illiterate person to manage his/her property , and getting knowledge is required to manage his/her property. Hence, it can be concluded that how knowledge is important to manage and possess ones property properly.

\subsubsection{Oral Literaturesthey usedon theimportance of Patience in Different Aspects}

\subsubsection{Short Sayings}

i. It is gradual process that we become free from oppression; otherwise, if it is in hurry, the result can be as a person who has taken out baby by force from inside the cow. (Gabrummaa suutaan keessaa bahan; yoo ariifatan akka nama sa'a dorrobe harka garaa keessa kaahee ilmoo fuudhee taha. Namni akkanaa wa sadi dhaba).

Sayyid Haji Ali related to patience stated that, this person is missing three things in the above saying.

a. Ilmoon ni duutii ni dhaba (the calf because it will die)

b. Aanaan ni dhaba (milk)

c. Saatis ni miidhamti (the cow will be affected)

From the saying, it can be understood that it is likely difficult to get things over night and patience is the key to every success. It is similar to the proverb: Hyena in hurry bites a horn. 
4.1.3. Oral Literatures they used Related to Political issues against Slavery and the importance of Freedom

\subsubsection{Short Sayings (Quotes)}

$i$. "If you recognize yourself, you know about right and struggle" "Yoo of beekan waa'ee mirgaa fi qabsoo beekan."( Aman Nasha,2010 Fuula 152).

This short saying indicates that knowing oneself critically can lead a person to be confident enough, independent and leads for asking his/her right and community confidently. Furthermore, one can know how to struggle for his/her right positively.

\subsubsection{Oral Literatures they used on the issue of Hardworking against Poverty}

The two famous persons used oral literatures in their speeches to teach youngsters and other people about the importance of economic development against poverty through hardworking as follows.

\subsubsection{Short Story}

a. Once upon a time, one person made grain store and sold it to stay alive; sayyid H/ Ali Wale observed this persons job and took him to fertile land (farm) and then told him, "your living period will be minimized or you will face harm if you do not produce harvest. (Gaaf tokko Sayyid Haaji Alii Walee namicha qafoo midhaanii dhahee gurguratee ittiin jiraatu argan. Isaanis, namicha kanaan "koottu”, jedhaniin. Sana booda, lafa qonnaaf taatu itti argisiisanii "yoo ati lafa tana hin qotin umriitu si dhuma”, jedhaniniin jedhama).

From this, it can be comprehended that doing more profitable work is mandatory. His speech also indicates that experience sharing is important why because this person destroyed forest daily and the benefit he got selling it even didn't assure his family food security. But working at farm is more advantageous. "Umriin si dhuma" is not a curse but it is used to indicate heavy work harms your health.

b. Once up on a time, one person came to Sayyid H/ Ali and told him, "I have seven miiddee of land (one 'midde' takes one day to cultivate it with oxen), but I produce few products." Sayyid H/ Ali replied, "It is better to cultivate/plow one 'miiddee' seven times instead of plowing seven middee once). (Namichatu Sayyid H/ Aliitti dhufe, "lafa miiddee torba qaba; garuu homaa hin argadhu” jedheen. Isaanis, "Miiddee torba qoturra middee takka yeroo torba qotuu wayya" jedhaniin jedhama.

The message shows that even big thing is valueless or fruitless if it is worked on it shallowly; it is not doing a lot of things that determine productivity, how to do it has large contribution.

In his life, Sayyid Haji Ali, he used to teach people using different methods. For example, he taught them how to protect their properties from thief. In all places, where he spent night, he ordered the people to tie his horse both legs-the front and the back, and also command them to assign a person who looks after it; in addition, he told them to allocate another person who observes the person who looks after the horse.("Bakka bulu maratti gaangee miilaa fi harkaa naa hidhaa, nama eegullee itti naa godhaa, nama nama sana eegullee itti naa godhaa" jedhan). The message reveals that one can learn from the above story that how keeping ones property is very necessary and it resembles with governments' security force.

c. One day, Sayyid Haji Ali Wale Wako gathered people and ordered them to plow the land (farm). People continued plowing the land until the sun down. As a result, they asked him, "Shall we release yokes from oxen because it is approaching to dark." He replied, "Is it getting dark as a person's face darkens while she/he begs crop or harvest?"

As data collected from interview and FGDs indicates, Sayyid Haji Ali Wale Wako, in his life, played a great contribution. He used to motivate his people for the development as they not to be dependent using oral literature. He encouraged people to work hard. The above short story tells us what he did with the attractive speech he made.

Furthermore, it can be concluded that he taught people practically as begging is very bad. To be free from it working day and night is paramount. A message can be understood from the story is that experts should teach people practically and learning is more understandable if it is supported with practice. In addition, consistency on job and working own work firmly is necessary as well as a person whom begs someone something hates a beggar.

\subsubsection{Oral Literature they used towardsHope and Future Analysis}

4.1.5.1. Short Stories (Seenaa Gabaabaa)

i. Sayyid Roba analyzed future things; for example, in 1905, he predicted " a certain time in which offspring do not respect parents and Oromo people are pushed from their property will come in the future"

He foretold that there is a time of a year in which horses starve whereas donkeys fatten, educated persons are engulfed while uneducated govern the country, oxen plow land the whole day, but they do not get grass and tied and stand the whole day (Bara fardi yaratee harreen gabbattu,bara hayyuun (beekaan) ukkaamamee wallaalaan biyya bulchu, bara sangaan qotaa oolee, lafa deemee dheedu dhabee hidhamee dhaabbataa oolutu dhufa (Amaan Nasha, 2010: 70). Another points he foresighted, being at that time, "There will be a time in the future, which individuals who come to Oromia only with bare donkeys be respected while aboriginal people will be lowered. 
Sayyid Roba in his speech predicted that Oromo people will face challenges and enter into dark in all cases. However, after that, the survivors will see the freedom. In addition, Aman(2010) stated Sayyid Roba as analytical person.

ii. $\quad$ One day, he went to Gura dhamole and he directed his face to person who had only one donkey, the person was very poor. Then he called and gathered people. Then, he ordered them to slay this donkey from the poorest person. The people shouted at him, "oh! Our respected sayyid Roba, how do we slay this donkey? The person is the poorest of our village."Sayyid Roba resisted them saying, "you must slay it." After so many arguments, they slew the donkey. Then, he, sayyid Roba, took the person to Sabro (found in Gindhir Woreda), and gathered people by saying, "Sabro! Sabro! I committed crime: or faced compensation, so support me". They collected a lot of quintals of cereal crops, and cattle. He then gave to the person whose donkey was slain. As a result, the person became rich.

Message: work hard; people should support each other, and no need of relying on small business. Neighbors and relative should identify poor persons and help them.

\subsubsection{Oral Literatures for giving critical attention and reasonable for something}

\subsubsection{Short Saying}

i. $\quad$ Sayyid Haji Ali Wale sayid "I did not eat except delicious food; I did not wear except white, and I did not ride except white" (Mi'aayaa malee hin nyaanne; adii malee hin uffanne; adii malees hin yaabbanne.)

The elders stated the above saying as Sayyid Haji Ali Wale intended to use them. In this regard, "I did not eat except delicious food" meansthat he does not eat food without feeling hungry, so it is delightful for him. In this condition he eats the food properly. The secondsaying "I did not wear except white" meansthat he does not wear unwashed cloth even if itis old; this implies that how much he gives care for his wearing. The last saying "I did not ride except white"; meansthat he does not walk on foot long journey except having something to ride either mule or horse or other transport.

The messages of the quote teach youngsters and other people to be reasonable to do something, to be careful for their wearing and use transport to save their time while they need to go long voyage.

\section{Conclusions and Recommendations}

\subsection{Conclusions}

It can be understood from the findings that the speeches that Sayyid Roba Garbi and Sayyid Haji Ali Wale made became oral literatures in the long run. They also had been using different genres of literatures like short sayings, short stories, proverbs, blesses, curses, and songs. It can be concluded that the oral literatures they are short in structure and have broad meaning. These oral literatures are fragmented and do not get due credit. The two famous persons were using these oral literatures to create awareness of youngsters, elders, and other classes of society towards the issue they need to direct. For instance, they used oral literatures to teach the importance of education, the status of literate persons, methods of managing and protecting properties, culture of hard working, the fruit of patience and so on. Their oral literatures also are used to teach different classes of society against bad practices like deforestation and begging. They had usedoral literatures to teach people something practically and with sharing experience.

In summary, the oral literatures in the speeches of the two persons have genres like short sayings, short stories, proverbs, blesses, curses and others. These genres were used to instruct, direct, offer advice and guide youngsters and other social classes towards education, social issues, hardworking, patience, on how to use and manage their properties etc.

\subsection{Recommendations}

As it can be understood from the research findings, Sayyid Roba Garbi and Sayyid Haji Ali Wale had used many types of oral literatures in various aspects. Their oral literatures have been used in the past and up to date. In line with this, the following recommendations were forwarded for different stakeholders on the basis of the findings and the conclusions of the study.

$>$ People give attention to the talk of famous persons, elders and other individuals, for they can teach, advise, guide and directyoungsters and people on social, economic, unity, hardworking and other issues using oral literatures in various aspects. Therefore, educators can use oral literatures to create the awareness of youths towards education. Besides, political leaders, local administrators, communicators, media workers can use oral literatures while they talkabout various issues on the stage.

$>$ The oral literatures used by the two famous personsteach people to have consistency on job and working own work firmly.Moreover, it teaches how education is important and basic for everything. They had been teaching how education is important to manage and use properties properly. Thus, people can also use those oral literatures to teach each other on how to manage their properties using oral literatures in different contexts. 
$>$ Different individuals can use the two famous persons' oral literatures on how to protect their properties from thief, particularly government leaders. In turn, they canalso teach youngsters and other individuals on methods of protecting their properties using oral literatures.

$>$ The oral literatures that were used by Sayyid Roba Garbi and Sayyid Haji Ali Wale can teach against bad practices in the society. For example, deforestation, begging and so on. Hence, the concerned bodies can use their oral literatures to encourage people to work hard and hate beggar.

$>$ The concerned bodies like cultural experts, language experts, researchers' of the area should collect, write, and analyze different oral literatures used by other famous persons in order to keep them in written form and let it to be passed for the next generation.

$>$ There are a lot of Oromo indigenous culture, practices, philosophies and others. For instance, Afaan Oromo idiomatic expressions, the issue of kiila lixuu, Oromo cultural terminologies in Gada system and so on. Thus, different researchers should take roles to conduct independent research on such important issues to have them in written form and let to pass to the next generation.

\section{Acknowledgements}

We would like to thank different stakeholders for the successful completion of the present study. In this regard, our many thanks go to Madda Walabu University for covering the whole expenses of the study. It might be difficult for us if the university did not allocate the required budget. Second, we would like to thank the selected elders of Goro woreda to give sufficient data related to the issue under study. It might be impossible to have the paper in this form if they did not provide us the expected information via spending their precious time. Finally, we have special respect for Goro woreda's culture and tourism workers for facilitating us with written documents related to the two famous persons' history.

\section{REFERENCES}

Abrams, M.H. (1988) Glossary of Literary Terms 5th(ed). New York: Holt, Rinehart and Winston

Addisu Tolesa .(2005). Oromo literature, Geerarsa, and the liberation struggle, Indiana University press.

Amaan N. Huseen. (2017). Qabsoo Ummata Oromoo- Finqila Baalee: Baalee Roobee

Asafa Dibaba, (2011).The Poetics and Politics of Selale Oromo Folklore Research, PhD, Dissertation, Indian University press.

Berhanu Mathewos .(1986). An Analysis of Kambata Proverbs. Addis Ababa: Addis Ababa University.

Berhanu,M. (2013). Fundamental of literature,Addis Ababa,Alpha printers.

Binyam Yakob. 2005. 'An Analysis of Some Gender Besed Kambata Proverbs.' (M.A Thesis)Addis Ababa: Addis Ababa University.

Bukenya, A., Kabira, W. M., and Okombo, O. (editors, 1994).Understanding Oral Literature. Nairobi: Nairobi University Press.

Coffin, P, and H.Choen 1966. Folklore in America. New York: Doubleday and Company Inc.

Cuddon, J.A .(1992).The Penguin Dictionary of Literary Terms and Literary Theory. London: Clays Ltd, Ives PLC.

Denzin \& Y. S. Lincoln (Eds.), Handbook of qualitative research (pp. 105-117). London: Sage.

Dundes, A. (ed). (1993). The Study of Folklore. Englewood Cliffs: Prentice Hall lnc. Encarta @ encyclopedia. 2009.

Eshete Gemeda.(2007).African Societies and Egalitarian Values: Oromo Folk literature and Cultural studies in Contemporary Context.(Unpublished dissertation).AAU.

Finnegan .2012. Oral literature in Africa. Oxford. ( $3^{\text {rd }}$ Ed.): Oxford University Press.

Gacau, R. N. (1970). Kikuyu Folktales. East Africa Literature Bureau: Nairobi, Dore salaam and Kampala.

Guba, E. G., \& Lincoln, Y. S. (1994). Competing paradigms in qualitative research. In N. K. Harry, S. (1972). Dictionary of Literary Terms. New York: McGraw-Hill Book Company.

https://en.wikipedia.org/wiki/Sayyid 3/15/19

Jackson, M. (1982). Allegories of the Wilderness. Ethnics and Ambiguity in Kuranko Narratives. Bloomington: Indiana University Press.

Jeylan W. Hussein. (2005).The Functions of African Oral Arts: The Arsi-Oromo Oral Arts In Focus. African Study Monographs, 26(1): 15-58.

Kipuri, N. (1983). Oral Literature of the Maasai. Nairobi, Lusaka, Ibadan, and London: Heinemann Educational Books, Ltd.

Meider.2004. Proverbs: A Handbook. London: Greenwood Press

Melakneh Mengistu.(1990). "The Major Themes and Motifs of Southern Agaw Folktales.” MA Thesis, Addis Ababa University.

(2005). Map of African Literature. Addis Ababa: Biranna Enterprise.

Miruka, O. (1994). "Understanding and Teaching Proverbs". 
Mullikamas, K.(1975). Folklore. Bangkok: Ramkhamhaeng University press.

Muktar Ahmed \& Oumer Aliy. (2010). Thematic Functions of Oral Literatures in the Speeches of Legendary Oromo Heroes in Bale Zone, Oromia. (Unpublished Research article).

Musa A, Saddo. (2018). Seenaa Haaji Aadam Saaddoo: Finfinnee.

Okpewho, I. 1992. African Oral literature. Bloomington: Indian University Press. 1976.

Sikiru A, O. (2015). literature and the African Socio- Political Space. Published article.

Simpson, J. and Speake, J. (1998). Oxford Concise Dictionary of Proverbs. Oxford: Oxford University Press. 